\title{
The Single-Case Research of Coastal Contextual Learning Media on the Understanding of Numbers Counting Operation Concept
}

\author{
Suciati \\ Universitas Borneo Tarakan \& Yogyakarta State University, Indonesia, \\ cauchy_my@yahoo.com \& suciati.2016@student.uny.ac.id
}

Badrun Kartowagiran

Yogyakarta State University, Indonesia, kartowagiran@uny.ac.id

Sudji Munadi

Yogyakarta State University, Indonesia, sudji.munadi@uny.ac.id

Sugiman

Yogyakarta State University, Indonesia, sugiman@uny.ac.id

To understand the concepts or principles in mathematics, children who have a concrete operational stage need physical objects that can bridge abstract concepts in mathematics. This research aims to evaluate the influence of coastal contextual learning media on a child's understanding concept in the material of numbers counting operation. This research is a single-case research with the A-B-A withdrawal design. This research used dependent variable in the form of target behavior which consists of the understanding of integer counting operation concept material. Intervention in the form of the use of coastal contextual learning media was independent variable. The media used in this research were seashells that had been colored. The research subjects were 6th graders of one of the primary schools in Tarakan City of North Kalimantan Province, Indonesia. The instrument used to collect the data was a test consisting ten items. The data was analyzed with descriptive statistics in the form of analysis in conditions and among conditions. The research result shows that the coastal contextual learning media in the form of shells was effective to improve the understanding of concept in number counting operation for the research subject. It can be seen from the improvement of the correct answers on the test of understanding concept given.

Keywords: single-case research, understanding of concepts, learning media, contextual, number counting operation

Citation: Suciati, Kartowagiran, B., Munadi, S., \& Sugiman. (2019). The Single-Case Research of Coastal Contextual Learning Media on the Understanding of Numbers Counting Operation Concept. International Journal of Instruction, 12(3), 681-698. https://doi.org/10.29333/iji.2019.12341a 


\section{INTRODUCTION}

Contextual learning is a process of holistic education that aims to motivate students to understand the meaning of the subject matter which he had learned by linking such material in the context of their daily lives (Reese, 2002; Johnson, 2002). The emphasis on learning of learning based on the issue conducted independently by students, with a variety of contexts in a variety of situations. The needs and interests of students, the very note in the hope of learning can be an effective and efficient learning.

Furthermore Hadi (2017) stated that contextual learning allows students to connect lessons at school with the real context in everyday life so that it would be able to interpret it in everyday life. The concept of contextual learning is expected to help teachers connect the subject matter taught with real world so that students can help students connect knowledge possessed by its application in everyday life. Concepts presented will be directly connected with the experience of students. Learning activities are carried out in accordance with conditions that are often experienced by students, so students feel what they are learning is something related to our everyday lives.

Concept is the basis of thinking in mathematics. Concept is the abstract idea that allows a person to clarify an object or an event and then determine whether the object or the event are an example of the abstract idea or not (Baroody et.al, 2007; Bell, 1978). The understanding of a concept is one of the important things in learning mathematics (Baroody et.al, 2006; Kilpatrick et.al, 2001; National Council of Teachers of Mathematics, 2000). Due to the mathematical competencies rely on mastery of concept and procedure (Rittle-Johnson \& Schneider, 2014). Individual mastery of mathematical concept is important to develop other mathematical competencies. The understanding of concepts is required in order to be successful in learning mathematics.

Due to its characteristics which are abstract and cannot be observed by five human senses, mathematical concepts are often considered difficult by some students. It makes them have low ability in understanding concepts in mathematics. It also leads to how they understand the further concepts. Aminah, Kusumah, Suryadi, and Sumarmo (2018) explaining appropriate mathematical concepts mastery will help the students achieve good score in the content and subsequent mathematical process. Retnawati, Kartowagiran, Arlinwibowo, and Sulistyaningsih (2017) finds that one of the causes of students' difficulties in finishing Indonesian National Exam is because of a lack of understanding of students' concept of the material provided. By understanding a concept, a person will be able to apply the concept in the daily life.

One of the basic mathematical concepts that is difficult to understand by the students is integer counting operation concept. Based on the Indonesian national curriculum, the concept of integer counting operation is presented for 6th graders of the primary school. Subject is one of the students who had difficulty in understanding integer counting operation concept, especially counting operation between positive integers and negative integers. She is a 6th grader in one of the primary schools in Tarakan City of North Kalimantan Province. She often makes mistakes in the addition and subtraction between positive and negative integers. 
When a child is dealing with a concept, it is necessary to trace the cognitive process so that the concept can be understood (Tall \& Vinner, 1981). Primary school students in Indonesia are in the age of seven until 13 years old. Based on the stage of intellectual development proposed by Piaget (Garber, 2009), students in this age range are at a concrete operational stage. In this stage, students can think rationally and logically, but only limited to the concrete object around them (Wulandari et.al, 2013). Therefore, they need real objects to be medium to concrete the facts so that the concepts are more understandable and acceptable by the students.

To be able to understand the concepts or principles in mathematics, children who are in the concrete operational stage require physical objects that can bridge abstract concepts in mathematics. With the physical objects, children can learn concrete things that can be seen, heard, touched and kissed. The physical objects will be a symbol of abstract concept. The symbolization process will facilitate abstraction and is very necessary in mathematics (Çetinkaya et.al, 2018). This process can be done by using learning media in learning mathematics.

Streefland (1990) state that learning the concepts in mathematics is a long process through various levels of abstractness, therefore, the mathematics tools or media are required. Learning medium or teaching aids are used to clarify the material delivered by teachers so that the students can perceive it and remember it (Sundayana, 2014). Furthermore, Lillard (1996) states that learning process should be adapted to the context. In this case, the contextual is in accordance with the students' surroundings. Therefore, the use of medium or teaching aids should be adjusted and it based on their surroundings.

Piaget (Cowan, 2006) reveals that a learning process will be more effective if the students are involved in the learning process and interact with their surroundings. In addition, Zolthan P. Dienes (Bell, 1978) states that each mathematical concept can be understood well if it is presented with a concrete learning media. The use of leaning media by utilizing the potential of the area around the students can bring mathematical concepts closer to them. That effort will help to bridge abstract mathematical concepts in learning process by contextualizing the learning in accordance with environmental conditions (Minister of Education and Culture, 2017). By using appropriate leaning medium which matches local potential, it will maximize the use of learning resources from the students' environment.

Therefore, one of the efforts that can be done to help subject to overcome her difficulty in understanding integer counting operation concept is by using contextual learning media which is in accordance with her surroundings, in Tarakan City. As a coastal area, which is also the transition area between land and sea, Tarakan city has many characteristics and local potential. The potential is in the form of marine resources and fishery resources including of nomei fish, shrimps, crabs, shellfish, small shrimp, seaweeds, etc (Rizal \& Laga, 2012).

By utilizing characteristics and coastal potential in Tarakan City as the learning media, a learning process is not only just memorizing and fulfilling administrative target, but also emphasizing the ability to reconstruct and build the knowledge and skill through new 
facts or propositions they experience in their live (Hoogland et.al, 2016). By providing a series of real activities that are acceptable to the subject's common sense, the subject will have interesting and meaningful learning experience so that the subject will be able to understand a mathematical concept.

This research aims to evaluate the influence of the use of coastal contextual learning media on the understanding of numbers counting operation concept. Specifically, this research examines the relationship between intervention provided, which is the use of coastal contextual learning media on dependent variables (target behaviors). Target behaviors include: 1) the number and percentage of correct answers to the question given and 2) the duration to finish the task.

\section{METHOD}

\section{Research Design}

This research uses a single-case research design. Single-case research is designing to determine a condition required to change an individual's behavior (Mertens, 2014). The researcher used A-B-A withdrawal by eliminating the treatment to identify if the treatment was effective. The A-B-A withdrawal design is generally involve the baseline phase (A) and the treatment phase (B). Each phase consists several measurement sessions. The measurement of integer counting operation concept material is done on each session.

\section{Subject}

The research subject is a student 6th grader of one of the primary schools in Tarakan City in North Kalimantan Province, Indonesia. The subject is the 11-year-old girl and the second child of two siblings. Physically, the subject does not have disability that will affect the behavior. The subject had low ability of level target behavior of number counting operation especially on the positive and negative integer operation. It was identified from the observation on the learning process and analyzing the results of students' tasks. In addition, the students' achievement on Mathematics subject was good enough because it was higher that the average score and the criteria of success.

\section{Setting}

This research was conducted in the odd semester, academic year of 2017/2018. The research location was in the subject's classroom. The research was conducted after the teaching-learning process was over. Therefore, when the research was conducted in the classroom, there were only the subject, the researcher and a teacher as the observer who had to observe and record the interaction which occurred. In addition, the researcher also prepared a video camera to document the learning process. The data was collected continuously for a month.

Baseline (A) phase is a phase in which the subject is not given an intervention in the form of coastal contextual learning media. The subject learns from the learning model that is usually used. Treatment (B) phase is a phase in which the subject is given a treatment in the form of coastal contextual learning media. The learning media used were painted seashells. 
The activity in intervention phase is began by explaining the rule in using media of seashells to the subject. The researcher and the subject made an agreement as the rule of using seashell media. The number of seashells showed a number, while the color showed the value of the integer. The red seashell (Figure a) represents negative integer. The white seashell (Figure b) represents the positive integer. If both seashells are paired, the value is zero (canceling each other).

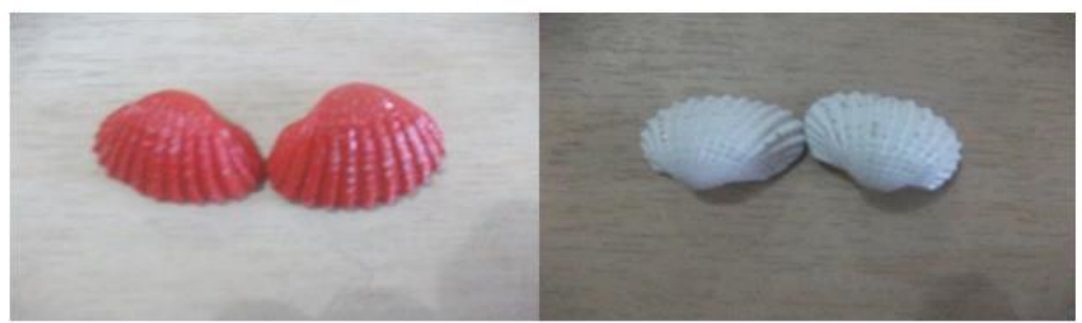

(a)

(b)

Figure 1

Media of Seashells

Afterwards, the researcher explained the use of teaching aids by using two colors at once. The similar thing was also done in using the teaching aids in terms of positive integer addition or subtraction, subtraction of positive integer and negative integer or vice versa and subtraction of negative integer. For example, the researcher performs the counting operation: $-7+2=\ldots$ To complete the operation, the researcher takes seven red seashells and two white seashells and arranges them as shown in Figure 2.

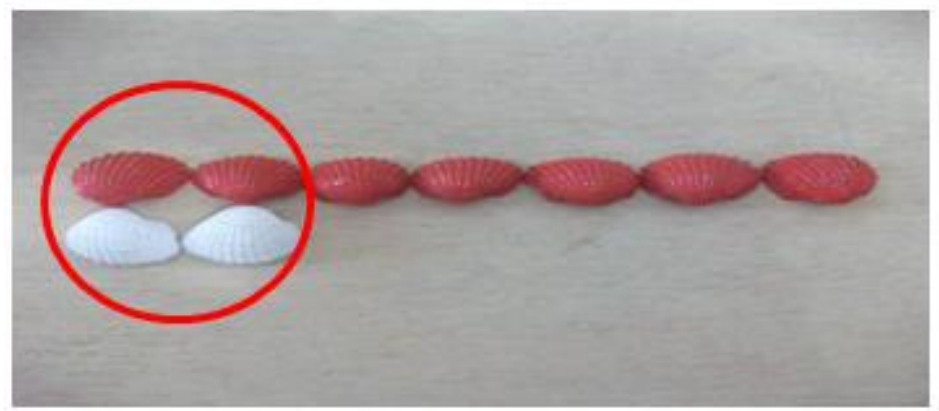

Figure 2

Media of Counting Operation: $-7+2$

After the seashells are arranged, there are four shells in pairs. The pairs consist of two white seashells and two red seashells. Therefore, both of pairs cancel each other and the value is zero. Based on the operation, there are only five seashells. Therefore, the operation result is five and because of the red color of the seashells, the value of number is negative. It can be concluded that the counting operation result of $-7+2$ is -5 . 


\section{Variable}

The dependent variable is a behavioral target, namely 1) the number and percentage of correct answers to the given questions and 2) the duration to finish the task. The subject's behavioral target level was measured by using the concept comprehension test on the negative and positive integer counting operation concept material. Furthermore, the observation of the subject was also carried out in the learning process. The subject's behavior in the learning process was recorded to watch the subject's activities.

The intervention in the form of the use of coastal contextual learning media became independent variable in this research. The researcher prepared painted seashells in two colors: white and red. Each color is the symbol of positive integer and negative integer.

\section{Research Procedures}

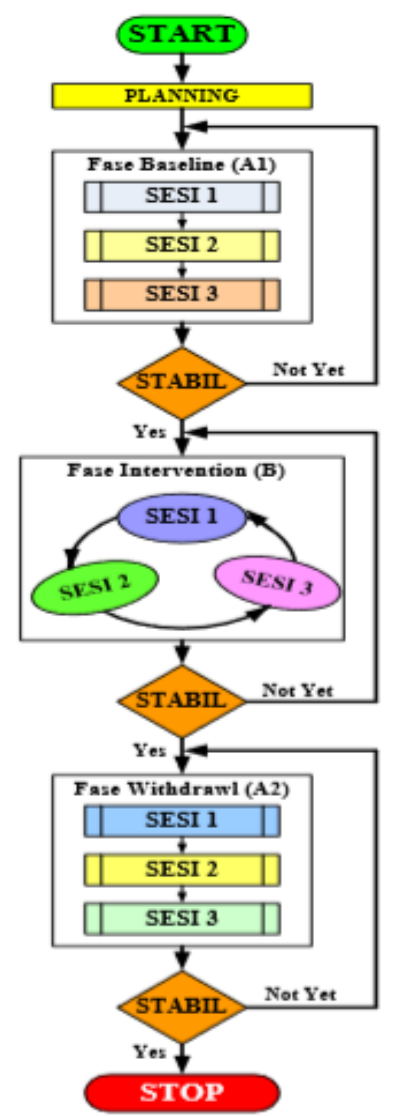

Figure 3

Diagram of Research Procedures 
The researcher prepared teaching-learning tools in the form of teaching-learning plan, media, concept comprehension test and observation sheets of the subject's activities. Each phase consisted of several measurement sessions (length of condition). The subject was asked to work on a test that measured the understanding of integer counting operation concept material in each session. The subject was free to determine which question item the subject wanted to solve first. There were 10 question items on each session with a time allocation of 30 minutes. The question items on each session were different but the assessment indicator was similar.

The test items were developed by the researcher with the collaborator teacher who also played role as the observer. Before using the test item, it had been validated by the experts. Seven experts were asked to give judgment to the content of the given test. As a proof of content validity, they analyzed the Aiken Index score on each item. The result shows that sixty items were in valid category because the lowest Aiken index score was 0.78 and the highest score was 0.90. After validation, the researcher tried out the test items to forty students. Based on the level of difficulty and item discrimination index, there were fifty items in good category and proper to be used. The items were arranged into five test packages. Each package consisted of ten items. The characteristics of the test device was based on the classical test theory as described in the following table 1.

Table 1

Characteristics of the Items Test

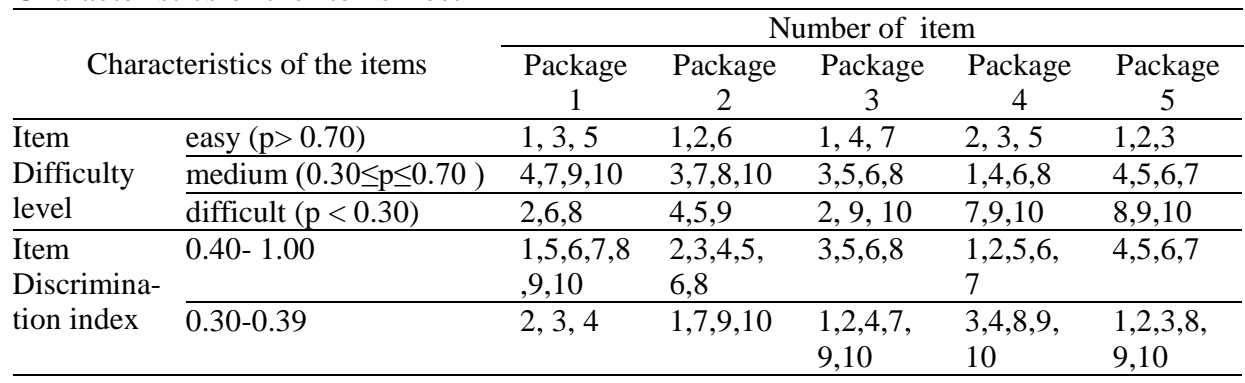

The question items given on each session have various levels of difficulty; high, medium and easy. There were three question items with high level and three question items with easy level while the rest were medium level. After finishing the test, the subject was given the correct answers. Reliability analysis using Alpha Cronbach model has shown that instrument has very high reliability. From the analysis results Alpha Cronbach coefficient value that is 0,823 .

The researcher also recorded the duration needed by the subject to finish the test. Examination on the target behavior the duration to finish the task in this research was done continuously. To find out whether data recording was reliable or not, percentage calculation was done based on the agreement of the observers. The result of this calculation on baseline phase (A1) was $80 \%$, treatment phase was $78 \%$, and A2 phase was $82 \%$. 
The result of research data was analyzed with descriptive statistics. There were two stages of the research data analysis namely analysis in conditions and analysis among conditions. The first stage was analysis in conditions in which the researcher analyzed point data on each condition (A1, B and A2). The analysis components on the first stage were the length of condition, estimation of direction and tendency of stability. The length of the baseline condition on each session was determined based on the stability of the data point on several sessions.

Meanwhile, the second stage was analysis among conditions. This analysis was conducted to identify the behavioral target level changes on each condition (A1, B and A2). In this stage, the components analyzed were changes in tendency and effect, changes in stability and behavioral target level.

\section{FINDINGS}

\section{Analysis in Conditions}

In accordance with the design used, the A-B-A design, the activity began with condition mapping in the initial baseline phase (A1). The mapping was done by recording the data point obtained based on the measurement result of the understanding of numbers counting operation concept and the duration to answer the questions. In this phase, the researcher did not give intervention in the form of learning media. The activity began with the researcher's explanation. And then, the subject was asked to answer the questions.

The subject was asked to work on 10 question items which measuring the understanding of integer counting operation concept. The subject was asked not to write anything if she did not understand the answer to the questions given. After finishing the test, the subject was given the correct answers and the researcher corrected the subject's answers. Afterwards, the researcher recorded the data point in the form of the percentage of correct answers of the 10 question items given and the duration to answer the questions.

Table 2

Data Point of A1 Condition

\begin{tabular}{llll}
\hline \multicolumn{2}{l}{ Baseline (A1) } & Correct Answer & Working Time \\
\hline Sesion & 1 & $(\%)$ & (Minute) \\
\hline 2 & 40 & 30 \\
\hline 3 & 50 & 26 \\
\hline 4 & 40 & 20 \\
\hline Mean & 40 & 24 \\
\hline
\end{tabular}

The data point obtained in the initial baseline phase (A1) shows the stability on five measurements. Therefore, there were 5 sessions of the initial baseline (A1). In the table 2 , the data point of A1 phase was obtained on each session in the form of correct answers and the duration. The length of A1 condition has 5 times measurements with the average of $42 \%$. The meaning of A1 condition is the initial condition before the intervention was given, subject was able to finish $42 \%$ or four out of 10 questions. The 
average of duration needed by subject to answer the questions is 24.6 minutes. The chart of duration to answer the questions given on each session is presented in the Figure 4 as follows:

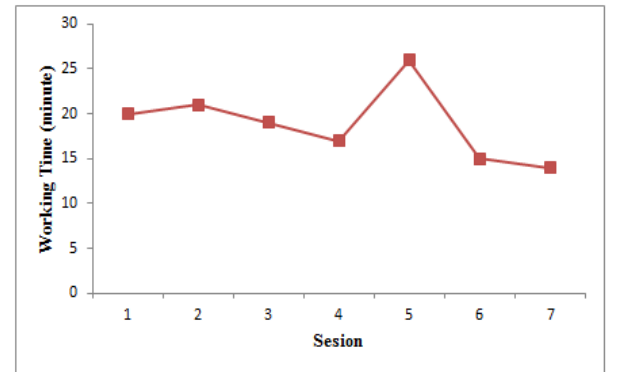

Figure 4

Chat of the Working Duration in the Baseline A1

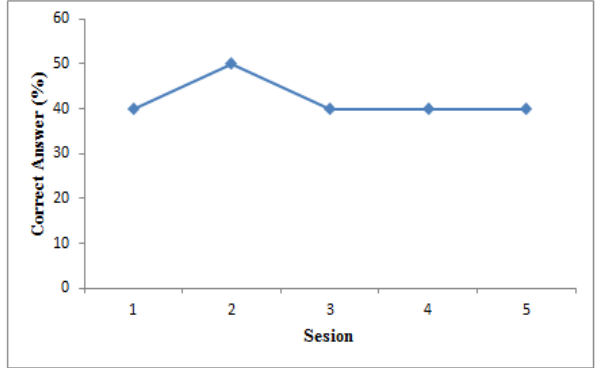

Figure 5

Chart of the Percentage of Correct Answers in the Baseline A1

In the A1 condition, the subject needs longer duration on the first session than on the next sessions. However, the subject needs less duration on the subsequent sessions. The percentage of correct answers on the second session is the highest percentage compared to the other four sessions. Hence, the less duration is needed when compared to the first session.

The percentage chart of correct answers on each session in the baseline A1 condition is presented in Figure 5. Based on the Figure 5, the initial baseline condition on the beginning sessions is not stable but on the next sessions is stable/ the instability on the beginning session is because the subject had not been able to adapt to questions given. The subject can adapt to the questions in the next sessions. This condition indicates that the intervention can be given. By using split-two method, the median can be found on each part and then the median is connected. The tendency will appear in the A1 condition. The stability tendency of A1 condition that has the average level of 42 with $15 \%$ of stability is presented in the Figure 6 as follows:

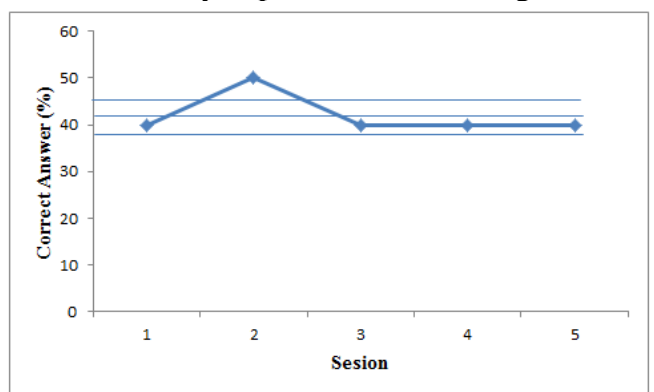

Figure 6

The Chart of Stability Tendency of A1 Condition 
By using the stability criteria of $15 \%$ or 0.15 and the highest score of the data point is 50 , the stability range obtained is $50 \times 0.15=7.5$. The mean level of the A1 condition is 42. Therefore, the upper limit of the stability range is 42 (mean level) +3.75 (a half of the stability range) $=45.75$ and the lower limit of the stability range is $42-3.75=$ 38.25 .

The data point percentage in the upper limit to the lower limit is $80 \%$, therefore, the chart of stability tendency of A1 condition on the Figure 3 indicates that the A1 condition is stable. Due to the baseline condition is obtained, the research is continued to the intervention phase (B). In the intervention phase (B), the coastal contextual learning media is given to the subject in the learning process.

After the intervention was ended, the researcher asked the subject to do the test consisting 10 question items which measures the concept understanding by using seashells media. The subject was asked to do the test as in the initial baseline condition. Afterwards, the researcher recorded the data point obtained. The length of the intervention conditions determined by the researcher was seven times of measurements. It was based on the consideration that in understanding the integer counting operation requires a lot of time. However, the researcher did not extend the intervention condition due to the effective learning day for the first semester would end soon. Therefore, the researcher decided to have seven times of measurement or seven sessions. It means that there would be seven data point of measurement result obtained after the intervention. In other words, the measurement was directly conducted after the intervention ended without a pause.

The data point of $\mathrm{B}$ condition is presented in the Table 3. In the Table 3, the data point of B phase is obtained on each session. The condition of intervention baseline (B) has the length of seven times of measurements with the average measurement of $64.285 \%$. In condition $\mathrm{B}$, Intervention condition, subject is able to answer correctly as many as six items. It increases two points from the previous phase. The duration in doing the test also increases. In this phase, the subject is able finish the test better than in Phase A1.

Table 3

Data Point of B Condition

\begin{tabular}{cll}
\hline Intervensi (B) & Correct Answer & Working Time \\
\hline Sesion & $(\%)$ & (minute) \\
\hline 1 & 50 & 20 \\
\hline 2 & 50 & 21 \\
\hline 3 & 60 & 19 \\
\hline 4 & 60 & 17 \\
\hline 5 & 80 & 26 \\
\hline 6 & 70 & 15 \\
\hline Mean & 80 & 14 \\
\hline
\end{tabular}

The working duration chart in Phase B is presented in Figure 6. 


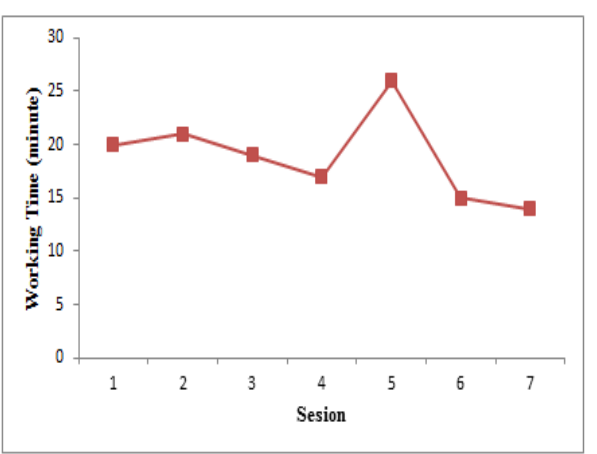

Figure 7

The Working Duration Chart in Intervention Condition B

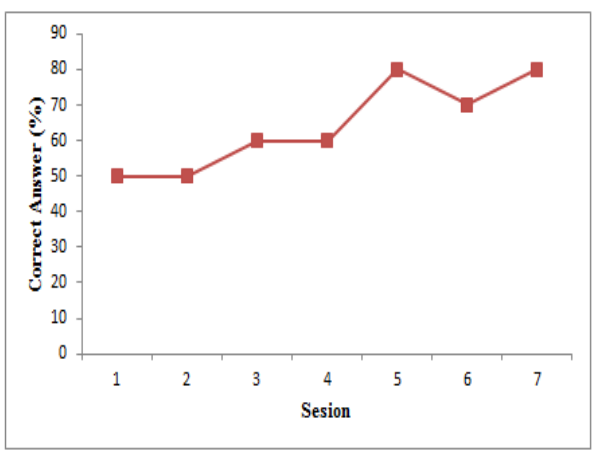

Figure 8

Chart of the Percentage of Correct Answers in Intervention Condition (B)

The stability tendency of Condition A1 which has the level average of $64.285 \%$ and $15 \%$ with stability is presented in the Figure 9 below.

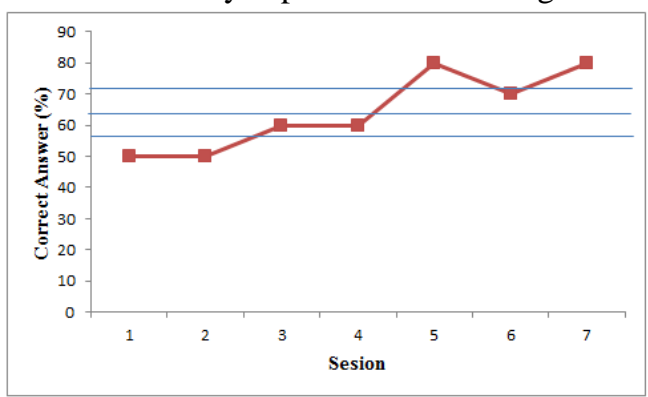

Figure 9

The Chart of Stability Tendency of B Condition

By using the stability criteria of $15 \%$ or 0.15 and the highest score of data point of 80 , the stability range is $80 \times 0.15=12$. The intervention condition (B) has the man level of 64.285. Therefore, the stability range is 70.285 and the range of low limit is 58.28. Thus, the chart of stability tendency of condition B in the Figure 7 shows that the condition B is stable enough and tends to rise.

After the intervention condition is done with the measurement on each session, the next phase is observing the final baseline condition (A2). Like the initial baseline condition (A1), the final baseline is also measured until the data point is stable. Based on the measurement result, the length of final baseline condition (A2) is five times of measurement or five sessions. The final phase is the intervention elimination in the final baseline condition (A2). The learning process runs as usual without using learning media as well as in the initial baseline condition (A1). The data point on each session is presented in the Table 4. The data point result of A2 condition is not much different from the A1 condition. The average of A2 condition with five times measurement is $40 \%$. 
Table 4

Data Point of A2 Condition

\begin{tabular}{cll}
\hline Baseline (A2) & Correct Answer & Working Time \\
\hline Sesion & $\%$ & (Minute) \\
\hline 1 & 50 & 16 \\
\hline 2 & 40 & 20 \\
\hline 3 & 40 & 17 \\
\hline 4 & 40 & 15 \\
\hline 5 & 30 & 13 \\
\hline Mean & 40 & 16.2 \\
\hline
\end{tabular}

It has two points lower than the initial baseline condition (A1). It means that after the intervention condition was stopped and subject returned to the initial condition of the learning process as usual, she was able to answer only $40 \%$ and the duration needed was longer.

The chart of duration in the A2 condition is presented in the Figure 10 as follows:

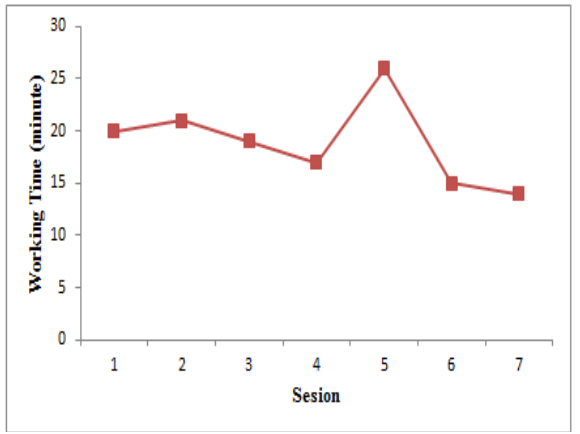

Figure 10

The working duration chart in The Condition A2

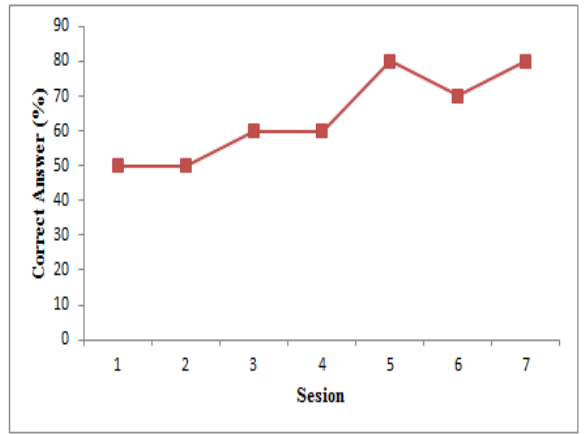

Figure 11

Chart of the Percentage of Correct Answers in the Condition A2

The data point of A 2 condition tends to decrease. The stability tendency of A 2 condition has the level of average of 40 and uses $15 \%$ of stability is presented in the Figure 12.

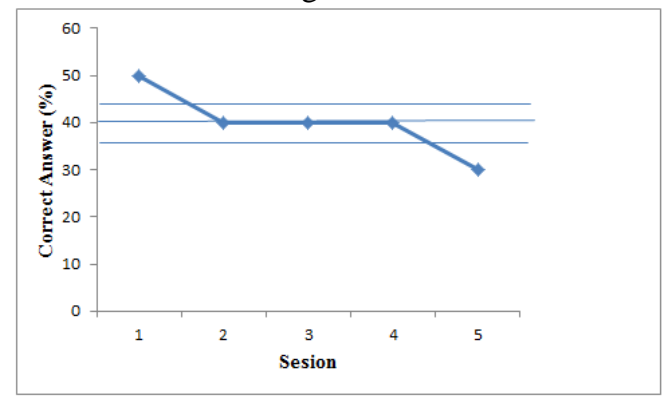

Figure 12

The Chart of Stability Tendency of A2 Condition 
The highest score of the data point in A2 condition is 50 and the range of stability is 7.5. Therefore, the upper limit of the range of stability is 43.75 while the lower limit is 36.25. Therefore, the chart of stability tendency in A2 condition in the Figure 11 shows that $\mathrm{A} 2$ conditions is stable enough.

\section{Analysis Result among Conditions}

To start analyzing the change among the conditions, it is necessary to look back at the stability of the condition. The stable data will precede the condition to be analyzed.

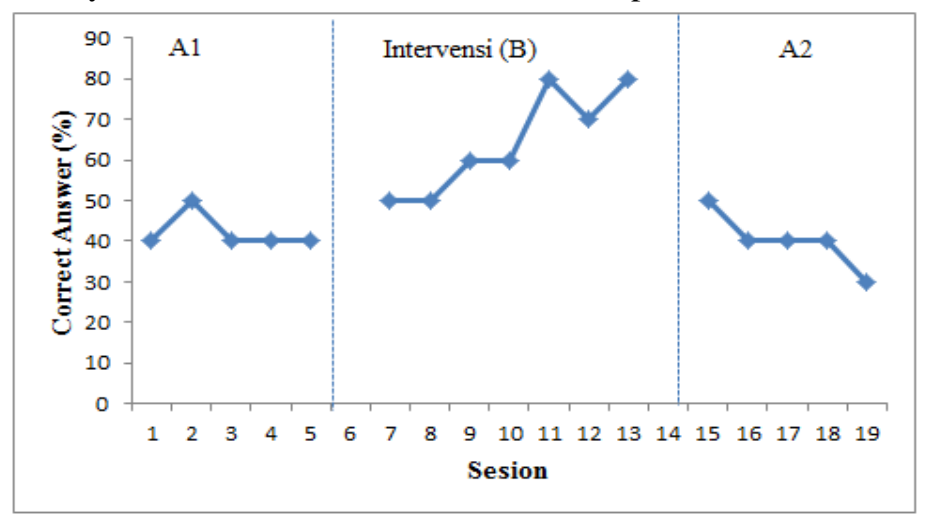

Figure 13

Chart of Analysis Result among Conditions

The analysis result among conditions shows that the data baseline A1 and A2 is stable. In the intervention condition, ability of subject to understand the concept increases even though in the 12th session there is a decrease in the percentage of correct answers. It is caused by the interference from other factors including health conditions, physical fatigue and others. Overall, the coastal contextual learning media in the form of seashells can increase the subject's understanding of integer counting operation concept. It can be seen in the third phase when the subject, subject was not given the intervention, the score of the subject's concept understanding was low.

\section{DISCUSSION}

This research aims to evaluate the influence of coastal contextual learning media on a child's understanding concept in the material of numbers counting operation. The learning media is seashells painted in white and red. The research result shows that there is an increase of the subject's understanding in integer counting operation concept. It is showed by the percentage of the amount of correct answers made by the subject in the intervention phase. The subject's ability in answering the questions correctly increased.

In phase A1 with five times of measurement, the subject is able to answer four items correctly. Those items have low level of difficulty. The subject has difficulty to answer the items with high level of difficulty. The items measure the ability to do the negative integer counting operation especially in subtraction. 
The first counting operation of subtraction encountered by the subject is positive integers. The concept of subtraction understood by the subject is the process of reducing the number itself. That concept understanding becomes a problem when she encounters negative integer subtraction. Therefore, the subject had difficulty in answering that kind of answer.

The data point on the beginning session of this phase shows various percentage of the amount of correct answers or data instability. On the next session, the third, fourth and fifth session, the point is stable. Based on the assessment result using observation sheet, the instability on the beginning sessions is caused by the subject has not adapted to the condition given. The subject was not familiar with the learning process which only involved the subject, the researcher and one observer.

In this phase, there is an adaptation process consisting of assimilation and accommodation. The assimilation process is when the subject assimilated her new knowledge and experience and her existing knowledge. Meanwhile, the accommodation process is when the subject adapts to her new knowledge and experience. In other words, the subject adjusts the scheme owned with her new knowledge.

The subject also looked anxious, nervous and unfocused. This can be observed from the video recording taken from each session. The subject makes movements such as daydreaming, playing a ballpoint, flipping a book and looking out the window. After several sessions, the subject can adapt to the test given and the learning process. The subject can focus on doing the test. She only plays once the ballpoint or makes movement once. Therefore, the subject is more comfortable doing the activity and the condition becomes stable in the fifth session. Due to the data has achieved the stability, the researcher does not extend the session in the baseline phase, the measurement in the baseline phase is stopped and the intervention can be given.

In the intervention phase, the amount average of correct answers increases to six points with the length of condition is seven times of measurement. In chart 11, the tendency of the amount of correct answers is in the third phase. In the phase B, there is a rising ascending chart, even in the $10^{\text {th }}$ and $12^{\text {th }}$ sessions, the percentage of the subject's correct answers is $80 \%$ or the total is eight out of 10 question items given. The subject is also able to answer the questions with high level of difficulty, number six and seven. The increasing number of the subject's correct answers shows that the subject is more mastering the material by using seashell as the learning media. The integer counting operation performed by the subject can be done contextually so that it is easier to understand.

The research result Perin (2011) shows that the contextualization process is an important process in every discipline to involve the students in understanding a material. Furthermore, Johnson (2002) states that contextual learning helps the students to develop their intellectual potential because it provides cognitive process used in critical thinking and creativity. In addition, it also provides a chance to use high-order thinking skills in real-life situations. By using seashell, the subject can visualize the problem given through the learning media. Therefore, the abstract concepts in the integer counting operation can be more concreted by using seashell as the learning media. 
When the intervention is stopped in the A2 phase, the subject's ability to have correct answer is low. The subject is only able to have four items of correct answers as well as in the A1 phase. In the beginning session, the subject has five correct answers or $50 \%$ of the total of questions given. However, in the next sessions, the percentage tends to decline even in the last session, the percentage is $30 \%$. In this phase, the subject is bored and try to divert her attention from the test given to the objects around her. The subject makes scribbles on the test sheet and writes down some sentences that are not related to the test given. The subject can only answer the question items with low level of difficulty.

By using contextual learning media in the form of seashell, the duration in finishing the test can be reduced. This certainly has an impact on the short time interval needed between getting information of correct answers and correcting the answers of the similar questions. The increase in the percentage of correct answers is caused by the subject who can easily determine the solution in a short time. This explains why the use of seashell as the learning media can increase the percentage of correct answers.

The use of teaching aids in the form of seashells which are colored is to illustrate positive and negative integers so that it can facilitate the subject on understanding integer counting operation concept. It is because of the learning practice by using learning media can provide valuable experiences for the students. Another research result (Binangun and Hakim, 2016; Suwardi et.al, 2016) shows that the use of teaching aids can make their experience more meaningful in building the knowledge they apply in learning and is able to improve the students' learning outcomes.

This experience is more memorable because the subject uses concrete object in her surroundings. The interaction between the subject and the learning media can facilitate the subject to construct her knowledge. The learning media can help the subject builds her new knowledge and uses the real object which can be directly touched by the subject. The real object in the form of seashell can makes the subject have an experience with objects and stimuli in her surroundings.

Slavin (2008) states that interaction among students is related to the task to improve their concept mastery. The subject connects new information with the experience of real life or her previous knowledge (Crawford, 2001). The initial experiences owned by the subject are symbols of number, counting operation connected with real object in the form of seashell so that the subject can develop her concept understanding which is more complex.

The use and the procurement of learning media is well made by the researcher so that the learning practice can be easier for the subject. Through the teaching aids, the researcher can make the abstract mathematical concept to be concrete. As stated by Suherman (2003), by using teaching aids, the abstract mathematical concept can become concrete so that the material is more understandable. The subject is more interested in the learning process because the learning media used is the real object, seashell. The subject's response in answering the test is faster. Therefore, she needs shorter duration.

The conceptual knowledge has a relationship with the procedural ability including counting (Rittle-Johnson \& Alibali, 1999). With the rise of the subject's understanding 
in integer counting operation concept, it makes the subject conducts the counting operation procedure. The counting operation (addition and subtraction) of positive and negative integers and between two negative integers is easier to conduct by the subject.

Learning by using contextual learning media in the students' surrounding can increase the students' conceptual mastery. This finding provides direct implication of learning implementation for primary school students in mathematics subject. On the other side, this finding also provides implication of the importance of leaning innovations to increase the learning quality in the class. The teachers should increase their knowledge and creativity to create meaningful and interesting learning process for the students.

The use of learning media for the students in their concrete operational intellectual development phase can help them in manipulating abstract mathematical concept. The learning media will be meaningful if the object used is a new thing for the students and it comes from their surroundings. On the other word, the students have not used the object before, but they are familiar with it. The object does not have to be expensive or new as long as it gives benefit and new experience for the students (Wulandari, et.al, 2016). By using reused object, it will be easier for the teachers to develop and make cheap and meaningful learning activity. Furthermore, the also can preserve nature and reduce pollution.

\section{CONCLUSION}

Based on the research result, it can be concluded that the intervention given by the researcher in the form of coastal contextual learning media which is seashells, is able to overcome the low ability of the understanding of integer counting operation concept material. The use of learning media can motivate the students to learn mathematics. The problems presented in the concept of formation process become more interesting by using resource around the student as the learning media. The interaction between the students and their surrounding will make their learning more enjoyable for the students.

\section{ACKNOWLEDGMENT}

The author would like to thank the Indonesia Endowment Fund for Education (LPDP) for their support on his study.

\section{REFERENCES}

Aminah, M., Kusumah, Y. S., Suryadi, D., \& Sumarmo, U. (2018). The effect of metacognitive teaching and mathematical prior knowledge on mathematical logical thinking ability and self-regulated learning. International Journal of Instruction, 11(3), 45-62. https://doi.org/10.12973/iji.2018.1134a.

Baroody, A. J., Feil, Y., \& Johnson, A. R. (2007). An alternative reconceptualization of procedural and conceptual knowledge. Journal for research in mathematics education, 38(2), 115-131. doi: 10.2307/30034952.

Baroody, A. J., Lai, M.-1., \& Mix, K. S. (2006). The development of young children's early number and operation sense and its implications for early childhood education. In B. Spodek \& O. N. Saracho (Ed.), Handbook of research on the education of young children (pp. 187-221). Mahwah, Nj: Lawrence Eribaum Associates Publishers. 
Bell, F. H. (1978). Teaching and learning mathematics (in secondary schools). Lowa: WC Brown Company.

Binangun, H. H., \& Hakim, A. R. (2016). Pengaruh Penggunaan Alat Peraga Jam Sudut Terhadap Hasil Belajar Matematika. JKPM (Jurnal Kajian Pendidikan Matematika), l(2), 204-214.

Çetinkaya, M., Özgören, Ç., Orakc1, Ş., \& Özdemir, M. Ç. (2018). Metaphorical Perceptions of Middle School Students towards Math. International Journal of Instruction, 11(3), 31-44. doi: https://doi.org/10.12973/iji.2018.1133a.

Cowan, P. (2006). Teaching mathematics: A handbook for primary and secondary school teachers. New York: Routledge.

Crawford, M. L. (2001). Teaching contextually. Research, rationale, and techniques for improving student motivation and achievement in mathematics and science. Waco, TX: CCI Publishing.

Garber, B. D. (2009). Developmental psychology for family law professionals: Theory, application and the best interests of the child. New York: Springer Publishing Company.

Hadi Sutarto. 2017. Pendidikan Matematika realistik: Teori, pengembangan dan implementasinya. Rajawali Press. Jakarta.

Hoogland, K., Pepin, B., Bakker, A., de Koning, J., \& Gravemeijer, K. (2016). Representing contextual mathematical problems in descriptive or depictive form: Design of an instrument and validation of its uses. Studies in Educational Evaluation, 50, 2232. doi: 10.1016/j.stueduc.2016.06.005.

Johnson, E. B. (2002). Contextual teaching and learning: What it is and why it's here to stay. Thousand Oaks, CA: Corwin Press.

Kilpatrick, J., Swafford, J., \& Findel, B. (2001). Adding it up: Helping children learn mathematics. Washington, DC: National Academies Press.

Lillard, P. P. (1996). Montessori today: A comprehensive approach to education from birth to adulthood. New York: Random House LLC.

Menteri Pendidikan dan Kebudayaan. (2017). Model Silabus Mata Pelajaran Sekolah Dasar/ Madrasah Ibtidaiyah Mata Pelajaran Matematika. Jakarta: Kementerian Pendidikan dan Kebudayaan.

Mertens, D. M. (2014). Research and evaluation in education and psychology: Integrating diversity with quantitative, qualitative, and mixed methods (4 ed.). London: Sage publications.

National Council of Teachers of Mathematics. (2000). Principles and standards for school mathematics. Reston, VA: Author.

Perin, D. (2011). Facilitating student learning through contextualization: A review of evidence. Community College Review, 39(3), 268-295. Retrived from https://files.eric.ed.gov/fulltext/ED516783.pdf 
Reese, S. (2002). Contextual teaching and Learning. Techniques. Vol.77, No 1.

Retnawati, H., Kartowagiran, B., Arlinwibowo, J., \& Sulistyaningsih, E. (2017). Why are the mathematics national examination items difficult and what is teachers' strategy to overcome it? International Journal of Instruction, 10(3), 257-276. https://doi.org/10.12973/iji.2017.10317a.

Rittle-Johnson, B., \& Alibali, M. W. (1999). Conceptual and procedural knowledge of mathematics: Does one lead to the other? Journal of educational psychology, 91(1), 175-189. doi: 10.1037/0022-0663.91.1.175.

Rittle-Johnson, B., \& Schneider, M. (2014). Developing conceptual and procedural knowledge of mathematics. In R. C. Kadesh (Ed.), Oxford handbook of numerical cognition, (pp. 1102-1118). Oxford: Oxford University Press.

Rizal, A., \& Laga, A. (2012). Komposisi Hasil Tangkapan Perikanan Tugu Di Perairan Kota Tarakan. Jurnal Harpodon Borneo, 5(1), 83-90.

Slavin, R. E. (2008). Cooperative learning, success for all, and evidence-based reform in education. Éducation et Didactique, 2(2), 149-157.

Streefland, L. (1990). Realistic Mathematics Education (RME). What Does It Mean? Contexts free productions tests and geometry in realistic mathematics education.

Suherman, E. (2003). Strategi pembelajaran matematika kontemporer. Bandung: Jica.

Sundayana, R. (2014). Media dan alat peraga dalam pembelajaran matematika. Bandung: Alfabeta.

Suwardi, S.; Firmiana, M. E. \& Rohayati, R. (2016). Pengaruh Penggunaan Alat Peraga terhadap Hasil Pembelajaran Matematika pada Anak Usia Dini. JURNAL Al-AZHAR INDONESIA SERI HUMANIORA, 2(4), 297-305.

Tall, D., \& Vinner, S. (1981). Concept image and concept definition in mathematics with particular reference to limits and continuity. Educational Studies in Mathematics, 12(2), 151-169.

Wulandari, S.; Suciati, \& Darmayasa, J. B. (2013). Pengembangan Paket Belajar Matematika Berbasis Kontekstual Pesisir Dengan Berbantuan Komputer Smp Kelas Viii Di Kota Tarakan. Paper presented at the Konferensi Nasional Pendidikan Matematika (KNPM) V, Malang, Indonesia.

Wulandari, S.; Suciati, \& Darmayasa, J. B. (2016). IbM Guru Sekolah Dasar di Kabupaten Bulungan Workshop Media Pembelajaran "Recycle Handmade" beserta Cara Membelajarkannya. Paper presented at the Seminar Nasional Pendidikan Matematika 2016 Prodi Pendidikan Matematika, Pamekasan; Indonesia. 